DOI 10.22460/jpmi.v1i3.219-228

\title{
Meningkatkan Kemampuan Berpikir Kreatif Matematis Siswa Kelas VIII MTs Negeri Sukasari Cimahi pada Materi Sistem Persamaan Linear Dua Variabel Menggunakan Pendekatan Open-Ended
}

\author{
Aini Fatwa Rahma ${ }^{1}$, Chandra Novtiar ${ }^{2}$, Asep Ikin Sugandi ${ }^{3}$ \\ 1,2,3 IKIP Siliwangi, J1. Terusan Jenderal Sudirman, Cimahi, Jawa Barat, Indonesia \\ ${ }^{1}$ ainifatwarahmaa@gmail.com, ${ }^{2}$ chandranovtiar@ikipsiliwangi.ac.id, \\ 3asepikinsugandi@ikipsiliwangi.ac.id
}

\begin{abstract}
Mathematical learning in each education level is more oriented through the increase of student's intelligence rather than student's creativity development. Sometimes, students learning outcomes are more important than the process of study. In the mathematic study at MTs Negeri Sukasari Cimahi, about SPLDV's, students in VIII G class have some difficulties in: 1) understanding the information of SPLDV's story questions and 2) remembering and aplicating the methods to finish SPLDV's questions. The open ended approach is used as one of the lesson strategy to increase the ability of the student's mathematical creative thinking. This research is conducted with 2 cycle, every cycle consist of 2 meeting. First, the researcher give some initial test to the students, then do the first and second cycle that use open ended approach. The result indicate that there is some progress in student's ability in mathematical creative skill, from the first test there are no student's score that achieved the limit score to pass. From first cycle to second cycle give increasing of score from $30,6 \%$ to $47,2 \%$. This is indicate that the student's mathematical creative thinking in VIII grade at MTs Negeri Sukasari Cimahi can be increased through open-ended approach.
\end{abstract}

Keywords: Mathematical creative thinking ability, linear equation system of two variables, open ended approach.

\begin{abstract}
Abstrak
Pembelajaran matematika di setiap tingkat pendidikan lebih berorientasi pada peningkatan kecerdasan siswa dibanding perkembangan kreativitas siswa. Bagi siswa terkadang hasil belajar lebih penting dibandingkan proses saat mereka belajar. Sehingga, siswa lebih mementingkan nilai daripada ilmu yang mereka dapatkan. Dalam pembelajaran matematika di MTs Negeri Sukasari Cimahi, mengenai materi SPLDV, siswa kelas VIII G merasa kesulitan dalam: 1) memahami informasi pada soal cerita SPLDV, dan 2) mengingat dan mengaplikasikan metode-metode penyelesain pada soal SPLDV. Pendekatan open-ended digunakan sebagai salah satu strategi pembelajaran agar terjadi peningkatan pada kemampuan berpikir kreatif matematis siswa. Penelitian ini dilakukan dengan 2 siklus dengan setiap siklus terdiri dari 2 pertemuan. Sebelum dimulai tindakan dilakukan tes awal kepada siswa, kemudian dilanjutkan dengan kegiatan siklus I dan siklus II yang menggunakan pendekatan open-ended. Hasil penelitian ini menunjukkan adanya peningkatan kemampuan berpikir kreatif matematis siswa terlihat dari ketuntasan hasil belajar siswa yaitu pada hasil tes awal tidak ada siswa yang nilainya melebihi KKM, pada siklus I terjadi peningkatan sebesar 30,6\%, pada siklus II terjadi peningkatan sebesar 47,2\%. Hal ini menunjukkan bahwa kemampuan berpikir kreatif matematis siswa kelas VIII MTs Negeri Sukasari Cimahi dapat ditingkatkan melalui pendekatan open-ended.
\end{abstract}

Kata Kunci: Kemampuan berpikir kreatif matematis, sistem persamaan linear dua variabel (SPLDV), pendekatan open-ended 
How to cite: Rahma, A. F., Novtiar, C., \& Sugandi, A. I. (2018). Meningkatkan Kemampuan Berpikir Kreatif Matematis Siswa Kelas VIII MTs Negeri Sukasari Cimahi pada Materi Sistem Persamaan Linear Dua Variabel Menggunakan Pendekatan Open-Ended

. JPMI - Jurnal Pembelajaran Matematika Inovatif, 1 (2), 139-144.

\section{PENDAHULUAN}

Peranan matematika penting di berbagai bidang, terutama terhadap bidang pendidikan. Maka dari itu, siswa harus menguasai matematika. Adanya pemberian arahan untuk siswa pada aktivitas yang mendorongnya dalam menguasai matematika. Matematika berpengaruh dalam meningkatkan daya berpikir siswa (Eminingsih, 2013). Karena matematika suatu pembelajaran yang membutuhkan pemusatan pikiran agar mengingat serta mengenal kembali aturan yang dipenuhi untuk memahami materi pembelajaran (Hamzah, 2000). Matematika diberikan di setiap tingkatan, agar siswa mempunyai kemampuan secara bernalar.

Tetapi nyatanya, dunia pendidikan lebih berorientasi tehadap peningkatan kecerdasan siswa dibanding perkembangan kreativitas siswa. Sedangkan kecerdasan dan aspek kreativitas siswa sama pentingnya dalam tercapainya suatu keberhasilan belajar. Biasanya siswa lebih memperhatikan hasil belajar mereka daripada proses saat mereka belajar. Sehingga, siswa lebih mementingkan nilai daripada ilmu yang mereka dapat dalam pembelajaran. (Supardi, 2015) menyatakan bahwa berkembangnya cara berpikir siswa merupakan kegiatan berpikir dari yang mulanya konkret menjadi berpikir abstrak. Kemampuan berpikir seseorang berkembang secara beragam. Guru harus mampu memahami kemampuan siswa sehingga pembelajaran dapat diterima baik oleh mereka. Jika guru tidak berhasil melakukannya, siswa kesulitan untuk memahami materi yang diberikan. Sehingga usaha untuk bisa menyampaikan pembelajaran itu disebut gagal.

Agar siswa mengalami kemudahan untuk memahami pembelajaran, siswa harus berlatih agar kemampuan berpikirnya dapat berkembang. (Munandar, 2009) menyatakan bahwa berpikir kreatif itu merupakan kemampuan dalam mengemukakan beberapa kemungkinan jawaban atau cara untuk menyelesaikan masalah. Oleh karena itu siswa harus mengembangkan kemampuan berpikir kreatif matematis yang dimilikinya. Siswa dibebaskan dalam mengemukakan pendapatnya dalam aktivitas pembelajaran dan menyelesaikan masalah matematis dengan cara yang mereka temukan sendiri. Dalam kegiatan menyelesaikan masalah siswa akan menemukan hal-hal baru, sehingga siswa akan mudah memahami materi yang dipelajari.

Pembelajaran matematika di MTs Negeri Sukasari Cimahi dengan materi SPLDV, siswa kelas VIII merasa kesulitan dalam: 1) memahami informasi pada soal cerita SPLDV dan 2) mengingat dan mengaplikasikan metode-metode penyelesain pada soal SPLDV. Untuk mengatasi kesulitan tersebut, adanya sebuah solusi yang tepat yaitu dengan peneliti melakukan penelitian tindakan kelas (PTK).

Dalam PTK ini membutuhkan suatu strategi pembelajaran agar tercapainya suatu peningkatan terhadap kemampuan berpikir siswa. Di sini pendekatan open-ended akan digunakan sebagai salah satu strategi pembelajaran agar terjadi peningkatan pada kemampuan berpikir kreatif matematis siswa. Menurut Shimada (Nuryadi, 2014), pembelajaran memakai pendekatan openended dimulai saat permasalahan diberikan pada siswa. Dari sebuah permasalahan, siswa akan menemukan berbagai penyelesaian masalah dan mereka dapat menentukan penyelesaian masalah dengan berbagai macam cara. 
Dalam aktivitas pembelajaran guru memiliki peranan penting, Sawada (Nuryadi, 2014) mengemukakan pendekatan open-ended dengan menggunakan macam ragam cara, siswa bisa menyelesaikan permasalahan tersebut. Guru kemudian membimbing siswa agar mendapat pengalaman dalam menemukan atau menyelidiki sesuatu yang baru dengan menggabungkannya pada pengetahuan yang sudah dipelajari sebelumnya. Pendekatan openended merupakan suatu kesempatan siswa mencari tahu proses atau cara yang mereka temukan sesuai kemampuannya dalam penyelesaian suatu masalah.

Untuk memecahkan permasalahan di atas, melalui wawancara terhadap guru mata pelajaran matematika di kelas VIII G MTs Negeri Sukasari Cimahi, disepakati untuk menerapkan pendekatan open-ended kedalam strategi pembelajaran. Agar adanya suatu peningkatan kemampuan berpikir kreatif matematis dalam materi SPLDV.

\section{METODE}

Penelitian ini memakai metode PTK terdiri dua siklus dengan tiap siklus memiliki dua pertemuan. Penelitian ini merupakan kegiatan pembelajaran untuk meningkatkan kemampuan guru dalam mengajar serta meningkatkan kemampuan siswa dalam menguasai konsep matematika. Subjek penelitian yang penulis teliti merupakan siswa kelas VIII G MTs Negeri Sukasari Cimahi Kecamatan Cimahi Selatan Kota Cimahi yang berjumlah 36 orang dengan materi pembelajaran SPLDV.

Untuk sumber data penelitian ini diambil dari nilai tugas yang diberikan kepada siswa. Pengumpulan data penelitian berdasarkan hasil tes pada setiap akhir siklus. Pengambilan data diperoleh dari data kuantitatif dan kualitatif. Data kuantitatif dilakukan dengan tes awal yang dilakukan sebelum dilaksanakan tindakan kemudian tes siklus 1 dan dilanjutkan tes siklus 2 setelah tindakan, sedangkan data kualitatif diperoleh berdasarkan lembar observasi.

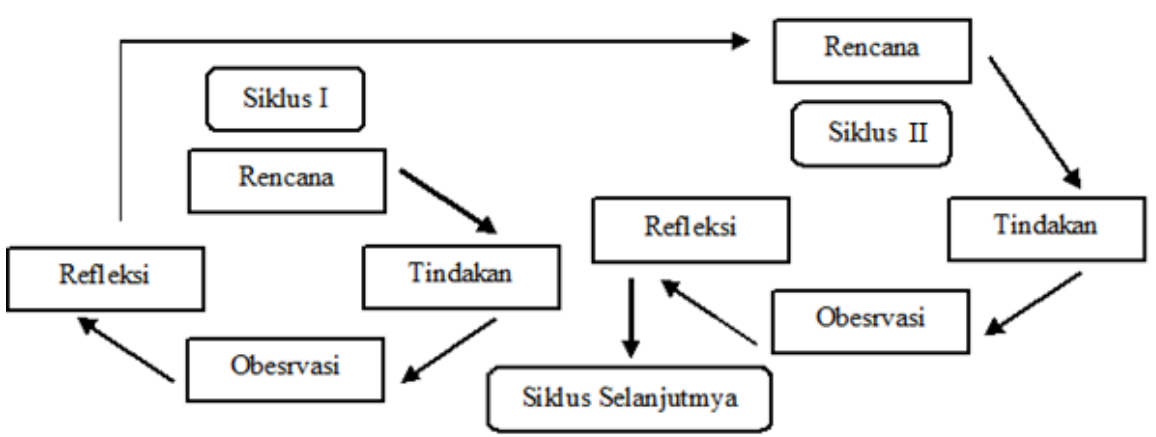

Gambar 1. Tahap dalam PTK

Pada tahap perencanaan kegiatan yang dilakukan yaitu: 1) menganalisis masalah pembelajaran yang telah dilakukan, 2) merumuskan/mencari pemecahan masalah, 3) merancang Rencana Pelaksanaan Pembelajaran (RPP) (pada sikus I dan siklus II), 4) mempersiapkan LKS untuk membantu dalam proses pengajaran, 5) berkoordinasi dengan guru yang bersangkutan, 6) mempersiapkan instrument penelitian.

Pada tahap pelaksanaan/tindakan, pembelajaran dilakukan sesuai dengan perencanaan yang dirumuskan. Sebelum pembelajaran, dilakukan pembiasaan berupa doa bersama. Setelah itu, 
agar suasana kelas kondusif dalam menyampaikan tujuan materi pembelajaran, siswa dikondisikan supaya siswa tertib sehingga siap untuk belajar. Kemudian guru membahas mengenai materi yang sudah siswa pelajari sebelumnya melalui tanya jawab.

Saat dilaksanakan kegiatan inti, adanya pembentukan kelompok yang beranggotakan maksimal 6 orang, lalu setiap kelompok mendapatkan LKS. Kemudian siswa mencermati petunjuk dan mulai menyelesaikan masalah yang ada dalam LKS. Siswa juga mengamati dan menjawab atas serangkaian pertanyaan dan petunjuk dalam LKS. Setelah itu siswa memberi kesimpulan dari materi yang telah mereka pelajari. Kemudian, dengan diskusi siswa mulai membuat pertanyaan yang memiliki kaitan dengan materi yang terdapat pada LKS. Siswa dibantu oleh guru dalam mengerjakan LKS. Lalu tiap kelompok mengirimkan perwakilannya maju ke depan kelas untuk menjelaskan kembali hasil diskusi kelompoknya dan kelompok lain menyimak penjelasan dari temannya.

Dalam kegiatan ini siswa terlihat sangat antusias dan juga memperhatikan temannya di depan kelas yang sedang menjelaskan. Kemudian dalam tahap ini, siswa memprediksi soal mengenai materi serupa dan menyelesaikannya. Setiap langkahnya telah direncanakan diamati dan dikumpulkan seluruh data, baik data selama kegiatan maupun data hasil pembelajaran. Hal ini bermaksud melihat peningkatan aktivitas serta hasil pembelajaran dari tiap-tiap siklus. Pada tahap observasi kegiatan yang dilakukan yaitu pengumpulan data yang cukup efektif untuk mendapatkankan informasi sebanyak-banyaknya dengan mengamati aktivitas pembelajaran dan hasil pembelajaran. Tahap ini dilakukan bersamaan dengan tahap pelaksaan pembelajaran.

Kemudian pada tahap refleksi hasil pengumpulan data yang diperoleh setelah pelaksanaan tindakan, observasi, didiskusikan, dianalisis dan dilihat kelemahan-kelemahan pada tahap siklus sebelumnya dan diperbaiki pada pelaksanaan tahap siklus berikutnya. Keberhasilan dilihat dari dua segi yaitu: 1) apabila minimal $85 \%$ proses pelaksanaan tindakan sesuai dengan skenario pembelajaran dan 2) apabila memperoleh nilai minimal 85\% siswa sudah mendapatkan nilai minimal 73. Berikut adalah jadwal pelaksanaan PTK.

Tabel 1. Jadwal PTK

\begin{tabular}{lllll}
\hline No & Hari/Tanggal & Waktu & Kegiatan & Ket \\
\hline 1 & Senin, 13 November 2017 & $13.40-15.30$ & Siklus I, Pertemuan 1 & \\
2 & Rabu, 15 November 2017 & $07.00-09.00$ & Siklus I, Pertemuan 2 & \\
3 & Senin, 20 November 2017 & $13.40-15.30$ & Siklus II, Pertemuan 1 & \\
4 & Rabu, 22 November 2017 & $07.00-09.00$ & Siklus II, Pertemuan 2 & \\
\hline
\end{tabular}

\section{HASIL DAN PEMBAHASAN \\ Hasil}

Penelitian dimulai hari Senin pada tanggal 13 November 2017 di kelas VIII G MTs Negeri Sukasari Cimahi. Sebelum melakukan siklus I, siswa diberikan tes untuk mengukur kemampuan kognitif siswa pada materi SPLDV. Siswa diberikan tes secara tertulis sebanyak 4 
soal uraian. Hasil tes tersebut dijadikan acuan awal untuk mengetahui kemampuan siswa. Berikut hasil tes prasiklus. Dari hasil pretes, ditemukan bahwa tidak terdapat ketuntasan hasil tes awal karena nilai siswa tidak melebihi KKM yaitu dengan rata-rata 17,5.

Pembelajaran siklus I pertemuan pertama dilakukan hari Senin tanggal 13 November dan pertemuan kedua pada hari Rabu tanggal 15 November 2017. Materi yang dipelajari adalah tentang SPLDV. Peneliti berperan sebagai pengajar dan pendekatan open-ended diterapkan pada kegiatan pembelajaran. Berikut hasil nilai tahap siklus I .

Tabel 2. Hasil Belajar Siswa (Siklus I)

\begin{tabular}{ll}
\hline Nilai & Banyak Siswa \\
\hline 100 & 6 \\
75 & 5 \\
70 & 6 \\
60 & 13 \\
50 & 6 \\
\hline Rata-rata & $\mathbf{6 8 , 7 5}$
\end{tabular}

Pada siklus I, terjadi peningkatan dari hasil pretes Untuk ketuntasan hasil belajar siswa pada saat siklus I ini terdapat 11 siswa (30,6 \%) dengan nilai rata-rata 68,75 meningkat dari hasil pretes yaitu 17,5 menjadi 68,75 .

Pembelajaran siklus II pertemuan pertama dilakukan hari Senin tanggal 20 November dan di pertemuan kedua hari Rabu tanggal 22 November 2017. Dalam siklus II tidak beda jauh dengan pembelajaran siklus sebelumnya, pada siklus ini hanya mengulas kembali beberapa materi yang sudah diajarkan di pertemuan sebelumnya dan tetap kondisi kelas dengan siswa duduk kelompok yang seperti pada siklus I. Nilai siswa pada penelitian siklus II sebagai berikut:

Tabel 3. Hasil Belajar Siswa (Siklus II)

\begin{tabular}{ll}
\hline Nilai & Banyak Siswa \\
\hline 90 & 6 \\
80 & 5 \\
75 & 6 \\
70 & 13 \\
65 & 6 \\
\hline Rata-rata & $\mathbf{7 4 , 7 2}$
\end{tabular}

Nilai siswa pada siklus II mengalami peningkatan dari nilai siklus I. Untuk ketuntasan hasil belajar siswa pada siklus II terdapat 17 siswa (47,2 \%) dengan rata-rata 74,72 meningkat dari hasil sebelumnya yaitu 68,75 menjadi 74,72 .

\section{Pembahasan}

Pada saat prasiklus hasil masih terlihat kurang maksimal sehingga hanya mendapat rata-rata 17,5. Berdasarkan hasil pengamatan dan data nilai siswa diperoleh: 1) siswa hanya menyelesaikan beberapa soal, 2) siswa tidak dapat mengerjakan soal, dan 3) rata-rata siswa belum cukup memenuhi KKM. Dari hasil data pada prasiklus diperlukan perencanaan yang 
tepat agar hasil belajar mengalami peningkatan, maka dari itu agar kemampuan berpikir kreatif matematis siswa mengalami peningkatan pada pelaksanaan siklus I, diadakannya suasana kelas yang menarik yaitu dengan cara membuat kelompok belajar menjadi kelompok kecil yaitu terdiri dari enam orang. Pada siklus I, siswa sudah mulai bisa memahami materi SPLDV, yaitu untuk menggunakan metode-metode untuk menyelesaikan soal. Hampir semua siswa mengalami kemudahan dalam menyelesaikan soal SPLDV menggunakan metode campuran yaitu substitusi dan eliminasi.

Dalam pembelajaran siklus I mulai terlihat nilai siswa mengalami peningkatan. Dari hasil (Tabel 2) tersebut, ditemukan adanya peningkatan kemampuan sesuai dengan harapan. Namun peneliti perlu merefleksi kembali pembelajaran, guna untuk mengetahui kemampuan siswa kelas VIII G dengan kegiatan pembelajaran yang sedikit berbeda. Pada siklus II, siswa semakin terbiasa dalam memahami materi SPLDV pada metode eliminasi, substitusi dan grafik, khususnya pada metode subtitusi mereka sudah mulai paham. Namun ada beberapa siswa belum paham mengenai penggunaan metode tersebut. Dari hasil data yang didapat, pendekatan open-ended diterapkan pada proses pembelajaran membuat kemampuan berpikir kreatif matematis meningkat. Karena saat prasiklus siswa belum memperoleh nilai yang melebihi KKM, kemudian pada siklus I mengalami peningkatan terdapat 11 siswa nilainya melebihi KKM. Agar kemampuan berpikir kreatif matematis siswa meningkat, peneliti kembali melakukan perencanaan, pelaksanaan dan pengamatan siklus II. Peningkatan terjadi dalam siklus II, yaitu terdapat 17 siswa nilainya melebihi KKM. Keberhasilan ini tidak lepas dari hasil diskusi peneliti dan para observer dalam menentukan masalah serta solusi yang diambil dari penelitian ini.

\section{KESIMPULAN}

Dari analisis data-data di atas disimpulkan bahwa pendekatan open-ended dapat digunakan sebagai upaya peningkatkan kemampuan berpikir kreatif matematis siswa kelas VIII G di MTs Negeri Sukasari Cimahi pada materi SPLDV. Serta adanya peningkatan hasil belajar siswa yang dilihat melalui ketuntasan hasil belajar. Pada siklus I, terjadi peningkatan dari hasil tes awal prasiklus yang awalnya tidak ada siswa yang nilainya melebihi KKM dengan rata-rata 17,5. Untuk ketuntasan hasil belajar pada siklus I ini terdapat 11 siswa $(30,6 \%)$ dengan rata-rata 68,75 . Hasil belajar kembali meningkat dalam siklus II, untuk ketuntasan hasil belajar terdapat 17 siswa $(47,2 \%)$ dengan rata-rata 74,72 .

\section{DAFTAR PUSTAKA}

Eminingsih. (2013). Peningkatan Hasil Belajar Matematika melalui Pembelajaran Kooperatif Tipe STAD pada Siswa Kelas VII E SMP Negeri 3 Batang. Lembaran Ilmu Kependidikan, 42(1), 30-35.

Hamzah. (2000). Pembelajaran Matematika I. Jakarta: Bumi Aksara.

Munandar, U. (2009). Pengembangan Kreativitas Anak Berbakat. Jakarta: PT. Rineka Cipta.

Nuryadi. (2014). Pendekatan Open-Ended. Yogyakarta.

Supardi. (2015). Peran Berpikir Kreatif Dalam Proses. Jurnal Formatif, 2(3), 248-262. 